\title{
THE FACILITATION OF A TEAM-BUILDING PROCESS: IMPLICATIONS FOR
} MENTAL HEALTH

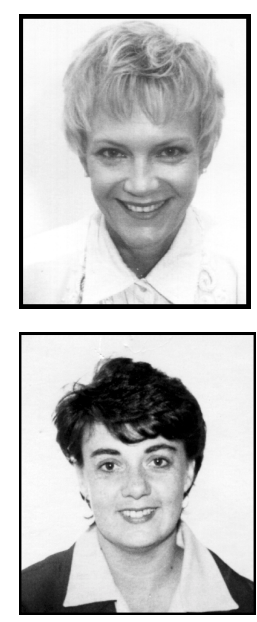

\author{
Antoinette Gmeiner \\ DCur - Professor, Psychiatric Nursing Science, Rand Afrikaans University
}

\section{Sandra van Wyk}

DCur - Senior Lecturer, Psychiatric Nursing Science, Rand Afrikaans University

\section{ABSTRACT}

The goal of this article was to explore and describe team members' experience of obstacles in their functioning as an effective team and their views of elements contributing to an effective and productive team. An effective and productive team could be a mentally healthy and emotional intelligent team. A qualitative, explorative, descriptive and contextual research design was followed utilising the phenomenological strategy with semistructured interviews and naïve sketches as method of data gathering. A purposive sample consisting of two teams with eight members each was used in this research. Data was analysed through a process of open coding and recontextualised within the given context of the specific business. A literature control was done to verify the data and compare it with other research done in the field of team-building. Strategies to ensure trustworthiness were adhered to. It was clear that these team members experienced many obstacles hindering their effective functioning as a team within the organisation. Obstacles included autocracy from top management, unclear direction within the company, and low motivation of team members resulting in high staff turnover, numerous days' sick leave, and low productivity. They also experienced dysfunctional lines of communication, mistrust and ineffective interpersonal relationships. Poor problem-solving skills together with a lack of self-awareness were also described. Participants identified elements contributing to an effective and productive team. On the basis of all the data gathered and the literature, guidelines for developing an emotionally intelligent team and emotionally intelligent individual team members were described in the form of a process outline.

\section{OPSOMMING}

Die doel van hierdie artikel was om spanlede se ervaring van struikelblokke in effektiewe spanfunksionering te verken en te beskryf, asook om hul menings ten opsigte van elemente wat kan bydra tot 'n effektiewe en produktiewe span in te win. 'n Effektiewe en produktiewe span kan ook 'n geestesgesonde en emosioneel intelligent span wees. ' $n$ Kwalitatiewe, verkennende, beskrywende en kontekstuele navorsingsontwerp is gevolg met die gebruik van ' $n$ fenomenologiese strategie om data in te samel deur middel van semigestruktureerde onderhoude en naïewe sketse. 'n Doelgerigte steekproef bestaande uit twee spanne met agt lede elk, is gebruik. Data is geanaliseer deur middel van 'n proses van oop kodering en ge-rekontekstualiseer binne die konteks van die spesifieke besigheid. 'n Literatuurkontrole is uitgevoer om data te verifieer en met ander soortgelyke navorsing te vergelyk. Strategieë om vertrouenswaardigheid van die navorsing te verseker, 
is gevolg. Dit was duidelik dat hierdie spanlede verskeie struikelblokke ervaar wat hul verhinder om effektief as spanne binne die maatskappy te funksioneer. Struikelblokke was onder andere outokrasie vanaf topbestuur, lae motivering van spanlede wat 'n hoë personeelomset tot gevolg het, talryke dae siekteverlof, en lae produktiwiteit. Spanlede ervaar ook disfunksionele lyne van kommunikasie, wantroue en minder effektiewe interpersoonlike verhoudinge. Daar is ook swak probleemoplossingsvaardighede en 'n tekort aan selfbewustheid. Deelnemers het daarna elemente wat sou kon bydra tot 'n produktiewe en effektiewe span, geïdentifiseer. Op grond van al die ingesamelde data, asook die literatuur, is riglyne vir die ontwikkeling van ' $n$ emosioneel intelligente span asook emosioneel intelligente spanlede in die vorm van ' $n$ proses raamwerk beskryf.

\section{BACKGROUND AND RATIONALE}

Teams and teamwork have survived as one of the crucial foundations of management since the early 1950's. Although the need for team development was identified some time ago, the concept of teambuilding and team-based organisations has changed throughout the years. The process of teambuilding initially focused on social interaction and interpersonal relationships (Phillips \& Elledge, 1994:1-2). This however has now changed to focus on both how team members relate and how work is completed. Focus is now also on empowerment as a social process of recognising, promoting and enhancing people's abilities to meet their own needs, solve their own problems and mobilise the necessary resources to feel in control of their own lives (Black, Everett, Green, Krilyk \& Van Berkel, 1994:11).

The team-building approach yields major organisational benefits, such as improved quality, higher levels of job satisfaction and use of creative energies of all those within the organisation (Lengacher, Mabe, Van Cott, Heinemann \& Kent, 1995:51). It can also lead to greater achievement of goals, delivery of services improves, staff morale increases and therefore client satisfaction improves as well (Antai-Otong, 1997:48).

Manthey (1994:5) adds to this ... "teamwork enables one to achieve any level of co-operation, coordination or collaboration". According to de Moville, Hogeda and Varnadore (1996:13-16) in the ever-changing world of the $21^{\text {st }}$ Century, companies cannot survive the excitement, pain, opportunities and chaos of the business world without being a team-based organisation. In this way, change could be managed and organisations could be flexible in how they change. Organisations and their people will find personal and professional survival from having the flexibility to direct the currents of change. Strengths will multiply by working in teams and creation of a synergy that will infuse the workplace (de Moville, Hogeda \& Varnadore, 1996:12).

Effective teams have been studied and described in the literature through the works of Lewin (1951); Mc Gregor (1960); Argyris (1964); Parker (1990) and Varney (1989) (in Lengacher et al. 1995:52).

Knowledge of the elements of effective teams is critical to the survival of an organisation in the process of redesign. Effective teams are seen to have the following attributes: goal-directed, with roles clearly delineated; effective relationships and communication; outcome orientated within the broad scope of the organisation; and periodically assessed for progress (Lengacher et al. 1995:52). Effective teams have established visions, or goals that are accepted by all members of the team. Clear role responsibilities are defined for all participants, and how these roles and responsibilities interrelate. Communication is imperative and positive team norms are important. Outcomes are related to clear work role assignments and accomplishments within the entire organisation. A supportive atmosphere 
stimulates creative outcomes, as do group process and communications. Periodic assessment of interference in team-effectiveness is necessary to move forward to meet the vision and goals (Parker in Lengacher et al. 1995:53).

Together with all the above, the concept of emotional intelligence has arisen, where the focus is on the development of emotional literacy within teams as well as within the leadership of a team. Developing the five essential competencies of emotional intelligence, namely self-awareness, self-regulation, motivation, empathy and social skills will empower teams to excel in their work. This will contribute to greater productivity, reduce staff-turnover, increase motivation and improve the morale in any company (Goleman, 1998:3-13). A tool that can be used very effectively in enhancing personal, as well as team effectiveness, is the DISC profile. The DISC is a profile of how people act, or their behaviour. It merely analyses behavioural style, that is, a person's manner of doing things. The DISC can be done by using the "Styles analysis Instrument"(Bonsetter, Suiter \& Widrick, 1993:6010). Manthey (1994:5) supports the idea of personal and professional development; created by enhancing emotional intelligence ... "The skills we need for effective team membership are not different from those we need for successful life".

It therefore, seems imperative that organisations conduct research to determine what factors can contribute to the success of a team-based organisation, as the advantages of team-building seems overpowering ... "saving millions, doubling productivity and creating products and services beyond customers' wildest dreams" (Rennecker, 1996:40).

\section{PROBLEM STATEMENT}

A property and hotel owning group identified the need for assessment within their workforce and requested the researchers, as team-building consult- ants, to assess, plan and implement a team-building process, as they identified the need for quality improvement and team force. The researchers realised that team-building was imperative as team members displayed ineffective team characteristics, resulting in confusion amongst team members about clarity of their roles and expectations within this team, unclear mission and vision, lack of transparency, openness and communication between team members and management, top down decisionmaking, crisis management and lack of trust. These characteristics were displayed as a result of many dynamic and constant changes within the company.

This resulted in low productivity, lack of internal motivation, inability to take responsibility and authority for actions/decisions, conflict within the team and lack of commitment, negative financial implications and high staff-turnover which created a classic picture of complexity (chaos) within teams. Chaotic teams are teams that are confused, disorganised and out of control, where the outcome of any small input is unpredictable and where the actions/behaviours of the team members are irregular, aperiodic and dynamical (Elledge \& Phillips, 1989:272).

Team members proved to be without synergy, and they described feelings of mental discomfort. In lieu of the above, the following research questions were asked:

- What obstacles do team members experience in their functioning as an effective team?

- What are team members' views of the elements contributing to an effective and productive team?

- What guidelines could be described for the facilitation of team effectiveness and the promotion of mental health of team members?

\section{Objectives}

Objectives for this research are as follows:

- To explore and describe team members' experi- 
ence of obstacles in their functioning as an effective team.

- To explore and describe team members' view of elements contributing to an effective and productive team.

- To describe guidelines for the facilitation of team-effectiveness and the promotion of mental health of team members by facilitating emotional intelligence.

\section{RESEARCH DESIGN AND METHOD}

A qualitative, exploratory, descriptive and contextual research design was utilised (Burns \& Grove, 1993:28-29; Creswell, 1994:146), where researchers worked inductively to explore and describe team members' views on the elements contributing to an effective team and their experience of obstacles in effective team functioning within their context (Mouton \& Marais, 1990:204).

\section{Data collection}

Data was gathered by means of focus groups with team members (Krueger, 1994:16-20). To enrich data, team members were asked to complete a naïve sketch on how they view the team functioning and what obstacles they experience in reaching their goals as an effective team within the organisation (Giorgi, 1985:1, 8). Field notes were also taken (Wilson, 1989:343) to obtain supportive information and as a system for validating data gathered during focus group interviews.

\section{Sample}

A purposive sample (Burns \& Grove, 1987:218219) was utilised where the sample consisted of two teams with eight members each. These were the first two teams within the organisation to be included in team-building sessions.

\section{Measure to ensure trustworthiness}

Guba's model (in Lincoln \& Guba, 1985:289-331) was utilised to ensure trustworthiness in this research. The four measures used to ensure trustworthiness were truth-value, applicability, consistency and neutrality (Krefting, 1991:214-222). Using the strategy of credibility and applicability by applying the strategy of transferability ensured truthvalue. Consistency was obtained through the use of the strategy of dependability and neutrality by means of the use of the strategy of confirmability.

Criteria to ensure the trustworthiness included prolonged engagement in the field, where both researchers spend at least a year in the company and with the team, reflexivity of both the researchers and the team members, by utilising conversations and reflective journals. Member checking and working within a set paradigm of nursing research ensured structural coherence. Both researchers have extensive experience in the field of qualitative research; therefore researchers' authority was intact. A dense description of the whole research process was given throughout the research to ensure the transferability and dependability of the research process. A purposive sample was utilised, within a specific context and specific criteria for inclusion of this sample was set.

\section{Data analysis}

Data was analysed by means of the descriptive method of analysis by Tesch (in Cresswell, 1994:155). The steps in data analysis were as follows:

- Read through all the transcriptions to form an idea of the story line

- Think abut the underlying meaning and write notes in the margin

All similar topics are clustered together under major topics, unique topics and leftover topics

- The most descriptive wordings for topics will then be turned into categories. These categories will then be revised until final categories and sub-categories arise. 
Following the completion of data analysis, the literature from relevant and similar studies was used to recontextualise the data and to identify similarities and differences between the findings of this research and other related research (Morse \& Field, 1996:106).

\section{Ethical measures}

Strict ethical measures were adhered to during this research. These included informed consent of the team members, privacy, ensuring confidentiality and anonymity and providing team members with results (DENOSA, 1998:1-7).

\section{RESULTS AND DISCUSSION OF RE- SULTS}

After data collection and data-analysis, two main categories with sub-categories emanated from the experiences/views of team members in responding to the main research questions, namely:

- "Describe the obstacles you experience in functioning as an effective team"?

- "Describe your view on what elements are needed to function as an effective and productive team"?

Table 1: Categories and sub-categories on team members' experiences and views with regards to obstacles and facilitative elements in effective team functioning

\begin{tabular}{|c|c|}
\hline CATEGOFY & SUB-CATEGORY \\
\hline - Obstacles in effective team functioning & 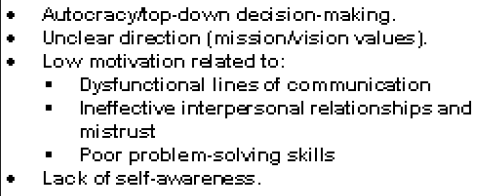 \\
\hline $\begin{array}{l}\text { - Elements contributing to an effective and } \\
\text { productive team }\end{array}$ & 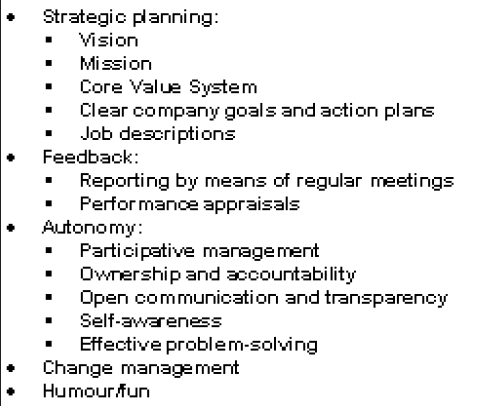 \\
\hline
\end{tabular}

The categories and sub-categories from data analysed are presented in table 1 .

These will now be discussed and supported by direct quotes from team members and a literature control to verify and recontextualise data.

\section{Obstacles in effective team functioning}

Team members described several obstacles inhibiting their day to day functioning in the organisation. Team members appear to blame top management for many of the obstacles and it appears that team members rather blame than be accountable, responsible and take authority for their own actions. There appear to be no shared vision/goals, no clarity around roles and relationships and a culture of mistrust and negative change was thus established.

Team members described these obstacles in an interrelated way as they influenced each other, therefore the following discussion will also be in an integrated manner, indicating the relationship between the sub-categories.

\section{Autocracy/Top-down decision-making}

Team members felt excluded from the process of decision-making within the organisation. They described receiving instructions to be carried out without understanding the end result/outcome. Decisions within the company were being made without involving team members and this resulted in them experiencing a feeling of insecurity and "being left" out.

As one team member recalls, "Decisions get made without us knowing of it ...it makes me angry and frustrated" and "we have no control over the driver" ... "people in the company decide and do things on their own".

When in such a situation, team members feel angry, isolated and worthless ... "I don't think I can make a difference to the company". This feeling of 
worthlessness and confusion contributed to the team members experiencing unclear direction with regards to a clear mission, vision and values within the organisation.

\section{Unclear direction (mission/vision/values)}

When the researchers, as consultants, were invited to assess the team for possible intervention, there was not a clear mission and vision statement or core value system. This contributed to the fact that team members described feeling lost and unproductive ... "like a motor vehicle driving to an unknown destination without a clear road map".

One stated, "We don't always know what this company is all about" and "I don't know which part I play within the bigger picture and what the bigger picture is all about". One team member also stated, "everyone want to know who's dealing with what ... what is my role within the team?" and "I don't feel that we have unity in where we are going to". Another team member clearly stated, "Until now I have never seen a clear vision or mission and I have always wondered what it really is?"

All the above factors directly contributed to the fact that team members described themselves as unmotivated.

\section{Low motivation}

Low motivation relates to many other obstacles team members experienced. They described decreased productivity and service to clients, as well as ineffective interpersonal relationships and mistrust of co-team members. In this whole process lines of communication collapsed and problemsolving skills were limited and non-creative.

As one member verbalised, "the lack of direction makes me feel impatient and I get angry and frustrated which have seemingly negative effect on my colleagues and it decreases the company morale" and "the rule of this company is - don't trust anyone".
Another one verbalised breakdown of communication as follows, "people are doing things on their own and we need more open, two-way communication" and "members don't give a chance to talk and they do not listen to one another".

Poor problem-solving skills are eminent in this process and one team member described it as follows: "we need to acknowledge each other when solving problems by making space for each other" and " $\mathrm{ev}$ eryone must have a voice and must be heard when introducing new ideas" and "we need to feel free when expressing our opinions, I want to feel as though my solutions to problems are also important". Another stated, "team members need to ask each other's opinion to a certain problem, each member is an expert in his field'.

Team members described a lack of self-awareness and experienced this as an obstacle in effective team functioning. This also contributed to an organisational culture of weariness and mistrust ... "treading on eggs" as some team members described it.

\section{Lack of self-awareness}

Team members expressed a need for self-disclosure and an understanding of their own thoughts, behaviours and feelings to be able to interact effectively with co-team members. This will also enable team members to draw on each other's strengths and have empathy for "weaknesses" and view "weaknesses" as a potential strength for the organisation. This will enable the entire team to grow on a personal and professional goal-directed level.

One team member remarked, "We need to get to know each other, our strengths and weaknesses through self-disclosure" and "we need to have more self-knowledge to cope with each other" also "personal relationships can be an obstacle if we don't know ourselves and learn to know the other team members". 
National and international literature on teams and team-building seem to focus on contributing factors towards effective team functioning. Various models/paradigms/conceptual frameworks on effective team functioning and the processes thereof are described. Little emphasis is placed on the experience of teams/team members functioning within a team or the possible obstacles they encounter in the team-building process.

Phillips and Elledge (1994:6-7; 1989:11) reiterate that it is common for organisations to use the phrase "teambuilding" without an accurate understanding of its objectives. The most important criteria for a successful team-building intervention, is a felt and identified need. The steps of team-building must begin with a request. This is the trigger that starts the whole intervention in motion. The team must feel a strong need to improve some basic condition or process that is interfering with the achievement of an organisational goal. Lynch (1981:241) supports this view and states that any team development starts with teams that are perceived to have a problem.

Literature states that any prospective team-building process should start off by working in an inductive manner to determine what the perceived problems/obstacles within the organisation are. Phillips and Elledge (1994:9; 1989:21-23) also say that team-building is essentially a process of gathering relevant and valid data about a team(s) and assisting this team(s) through the steps of data feedback, problem identification and action planning. Some of the most common ways of gathering data for team-building are interviewing, standardised questionnaires and other types of more inductive data-gathering (Freiburger, 1996:8; Lynch, 1981:243 \& Norville, 1983:43-47).

Phillips and Elledge (1994:7) have identified certain obstacles that signal the need for team-building. These are:

- Loss of production and output
- Increased number of complaints within the staff

- Conflicts or hostility amongst staff members

- Confusion about assignments or unclear roles

- Decisions that are misunderstood or not carried through properly

- Lack of interest and involvement from staff members (low motivation)

- Ineffective staff meetings

- Negative reactions towards the manager

- Complaints from customers and the quality of service

Adding to this, Rothermich, Kinnear and Beck (1996:16) state that some complaints within a dysfunctional team focus on salary, space and working conditions, while the vast majority of the complaints, as well as those that are the most bitter and seemingly beyond hope of resolution, focus on other people in the workplace. Many team members feel that they have to deal with co-team members whom they perceive to be self-centred, abrasive, non-cooperative and unappreciative.

They further describe an obstacle of "unpleasant surprise" as a behaviour that violates an expectation amongst individuals or groups. The outcomes of such patterns of behaviour are deadly. Under conditions of "unpleasant surprise" without constructive discussion and solution, individuals and groups begin to take sides.

"Unpleasant surprise" refers to top-down decisionmaking without input from the team. Constructive communication and responsible problem-solving begin to be replaced by gossip, self-righteous finger pointing and defence of territory.

Further obstacles preventing teams to succeed:

- Lack of intellectual power within the team;

- culture of the organisation favouring certain personality types;

- lack of team-role awareness;

- lack of overall vision and corporate objectives to guide the team; and 
allowing functional requirements to override team-role preference (Eggart, 1994:53-54).

Cultural resistance, team player problems and blurred goals or roles often hinder team development. This contributes to dysfunctional behaviours including aggression, competition, aloofness, shaming and blaming. Even if one team member displays any of these behaviours it can cause tension, resentment and anger within the team (Antai-Otong, 1997:48-50).

\section{Elements contributing to an effective and productive team}

Team members expressed specific and clear elements that could enhance team functioning and ultimately create a happy, productive and accountable team striving towards fulfilling company goals. It was important for researchers to take cognisance of these elements, as this was also an indication of what the needs of the teams in terms of team-building were.

\section{Strategic planning (structure)}

Teams expressed that a clear vision, mission, a core value system, clear company goals, action plans and job descriptions are elements that will ensure co-operation and harmony within the organisation and ultimately lead to efficiency and effectiveness.

One member stated, "we must all know what the company is all about and where we are heading towards ... we need a mission and vision" and "we need clear goals ... I want to know where we are going" and "a proper strategic plan in any company is very good". Another one said, "everyone wants to know what their job descriptions are and their expectations within the team" and "we need the ability to plan and to stick to it". "With clear core values, teams know what they buy into and can feel much safer".

According to Rennecker (1996:40) many variables have an impact on the quality and effectiveness of teamwork in achieving its goals, but few are as critical as having a clear defined mission statement. The mission statement serves throughout the life of the team as an anchor and guide for their work, aligning their efforts with the organisational goals and needs of the organisation.

Fitzpatrick (1996:47) also reiterates the importance of a vision together with a mission as he states " $a$ shared vision provides each team member with continuity, unity and a framework for commitment". Team member can use their vision as a marker to gauge progress towards achieving desired outcomes. Focusing on outcomes insures that cell activities and decisions are driven by the vision (de Moville, Hogeda, Varnadore, 1996:14).

A vision statement should be proposed by the leader but developed by all team members. This is a statement of how the members want to be perceived, what their norms are and what gives meaning to their work. Creating a vision forces them to take a stand for a preferred future. A vision channels teams' deepest values into the workplace and becomes a word picture of how they want their values to be lived out in their organisations. The leader must therefore ensure that team activities reflect the vision (Russel-Babin, 1996:233).

To function within an effective team, each member attempts to maintain equilibrium between his/ her internal values and beliefs and the external values, beliefs and expectations of the organisation. New beliefs and values therefore need to be created by the team members in the organisation to be effective and create high synergy teams (Lynch, 1981:243; Eggart, 1994:52). Synergy is the basic principle that a group of people working in unison can accomplish more than the same number of people working alone (Dalton, 1996:66). A team comes into existence and synergy when individuals join together for the purpose of resolving and achieving specific mutual objectives (Eggart, 
1994:50).

The top priority of all team members for the effectiveness of a team must be the accomplishment of team goals and not just personal ones (Dalton, 1996:66). A shared purpose and shared team goals not only directs a team's interaction with the consumers of their services, but also guides daily operations, team relationships and most importantly, the team decision-making process (Rush \& Shelden, 1996:136)

To clearly delineate roles, the leader of the team should have written job descriptions that define each individual's tasks within the organisation in broad terms. These job descriptions should be reviewed annually to ensure that they continue to support role statements, the vision and mission of the organisation (Prehn, 1996:40; Norville, 1983:40).

Problems with unclear roles cause many unpleasant surprises. Teams that work well over time minimise role difficulties through clear job descriptions and role negotiations, a process that clarifies what others expect of them and they expect form others (Rothermich, Kinnear \& Beck, 1996:19).

\section{Feedback}

Team members spoke extensively about how feedback could contribute to effective team functioning. Feedback should also be a two-way process, where they receive feedback and also have the opportunity to give feedback and report-back. Regular meetings could enhance this where formal feedback structures can be in place.

One member described it as follows: "we need more feedback from each other about how we work and what we expect from each other" and "we need more feedback from our bosses and we need time to report back". Another added, "For a team to be successful, its functioning and progress need to be evaluated on a regular basis in meetings" and "we can only accomplish our challenges once we can have the opportunity to give feedback" and "meetings, even if only once a month, can help a team to implement feedback/report structures".

In these teams, no formal system of performance appraisal was in place, and teams perceived this as an obstacle blocking the creation of a winning team. For teams to feel secure and have clarified roles, a formal system of performance appraisal needs to be in place.

One member said, "Performance appraisals annually (at least) will definitely contribute to the success of this team" and "our shortcomings should be identified through a performance appraisal format for us to be able to plan ahead". Another added, "A performance appraisal framework will create a context within which more positive feedback will take place".

Report back by means of regular meetings provide the opportunity for team members to know exactly where they are going and what outcomes they can achieve, and team members will also know how each activity helps their advance towards the outcomes and goals. It is imperative that with all meetings, advance planning is critical to achieve a positive outcome. The ideas of team members need to be recorded in an appropriate format. This includes minutes, actions, decisions and all other possible outcomes.

Regular meetings provide all team members with an explanation of how failure to take responsibility, affects the team as a whole, moving away from the blaming or shaming phenomena (Antai-Otong, 1997:51). Black et al. (1994:15) proposes different ways in which team meetings can take place e.g. organising a dinner, developing an agenda and future actions, taking minutes, keeping files, regular seeking of outside advice and using individual networks of resources to add to collective ideas of team members. 
Performance appraisals provide a valuable framework for feedback and are recognised by virtually everyone who has a genuine interest in the work they perform. Feedback through performance appraisals tells you where you are now, and what needs to be done to get to where you want to go. Feedback in this manner can be defined as the information about the effectiveness of one's performance that is necessary for improvements in intentional behaviour. The manager could be seen as only one of the sources of feedback and may not be the most important one (Brodsky, Runcie, Lichtenstein, 1996:728-729).

Organisations that are rich in rewards are intrinsically valuable. They create a culture for positive attitudes, team members tend to be more open and communicate more freely with each other (Rothermich et al. 1996:19; Norville, 1983:39).

\section{Autonomy}

Team members describe that for teams to be effective and productive, team members need to have direct control and input regarding decisions that are made, and actions planned for goal-achievement, thus autonomy. Team members should also be accountable for their actions with authority. This is an empowerment process, whereby teams are then more accountable and take ownership for their actions. This could be enhanced through a process of open communication and transparency, effective problem-solving and a high degree of self-awareness.

Direct quotes from team members to support the above are as follows: "We need to be part of the decision-making process to avoid conflicting instructions". "There must be more open and participative communication between management and team members to have clarity on procedures in the organisation".

On ownership and accountability they said, "A personal challenge for me would be to take on more personal responsibility". "In a good team, members need to take on autonomy and responsibility". "We must be able to make meaningful suggestions and take responsibility to carry them out".

Team members felt very strong about effective lines of communication and transparency, which is an essential ingredient of participative management. One said, "Team-building could be effective in enhancing good communication". "We need to listen to one another and respect one another". "There must be good communication, as management and as a team it is necessary to work together and everyone needs to know each other's perceptions and opinions". "The ability to communicate is of crucial importance to be effective".

Team members added the following on the value of effective problem-solving skills as an attribute to an effective team: "Good problem-solving skills need to be learnt and practised". "Problems must be solved in an effective manner as they arise".

On self-awareness team members added: "Team members must get to know each other ... their strengths and weaknesses through self-disclosure". "Team members must acknowledge each other and make space for each other". "We must learn to really understand and accept each other". "We want to learn a lot more about ourselves".

Accountable work teams are based on the concept of self-management. Team members have the responsibility, not only for executing the work, but also for monitoring and managing their own performance. Coinciding with this is asking for feedback and providing feedback for others (Ashton \& Wilkerson, 1996:48).

For teams to be successful, real responsibility and authority must be transferred to them. The responsibility must be accompanied by a clear allocation of an appropriate level of authority. The team must be provided with the necessary resources to carry 
out the responsibility. The transfer of responsibility to the team ultimately frees the manager up for other work. Kneedler (1988:18) adds to this by saying that high performance teams can only be created by participative leadership and creating interdependency by empowering and freeing up.

Empowerment is a social process of recognising, promoting and enhancing peoples' abilities to meet their own needs, solve their own problems and mobilise the necessary resources to feel in control of their own lives. This will also help team members to own their jobs, to feel and behave as if one has the power over significant aspects of one's work. This enhances feelings of self-efficiency (Black et al. 1994:11-12). Skilful collaboration depends heavily upon open communication, interpersonal skills and transparency.

A context of open and honest communication must be created for a team to be effective. By keeping the lines open, team members can learn to anticipate other team members' responses. Through communication team members learn to share information, both good and bad in an open and honest way. Open communication also enhances responsibility. Team members will know when they are doing a good job. For communication to be effective an environment of trust needs to be created where members can feel comfortable to share thoughts and feelings comfortably (Rush \& Sheldon, 1996:136-138).

Communication enhances interpersonal skills and team members get the opportunity to be trained in group problem-solving skills. Problem-solving skills are facilitated through a process of experiential learning where team members have the opportunity to learn problem-solving skills through exercises, tasks, case studies and activities (Lynch, 1981:246).

Self-awareness within the context of team-building fosters team effectiveness. Awareness of how individual characteristics effect team dynamics enables team members to develop an understanding of their similarities and differences which can be used in building team strengths and supports (Rush \& Sheldon, 1996:134).

Through self-awareness, team members become aware of their own personality types and how these qualities can contribute to goal-achievement. Members can learn to appreciate each other's strengths, realising and dealing with conflict, raising self-esteem and appreciating one another's differences. This can result in a rewarding team-building process (Crossley, 1994:79-80).

\section{Change management}

Team members experience the dynamic status of the organisation and therefore place emphasis on the importance of efficient change management as an element contributing to the creation of a winning team.

Direct quotes from team members are: "To deal with the changes, we must invite our CEO to some sessions to get to know what is going on". "Teams do not want to be in the dark ... tell them about changes". "I somehow feel left behind if changes occur so fast". "It's important to keep the staff and not to make so many changes".

Change always threatens organisational culture. Changes can strip down relationships and leave employees feeling confused, insecure and often angry. Employees need a sense of reality regarding what the context is all about. The necessary preparation for change needs to be in place. The lines of communication need to be open in order for the team members to be aware of changes that occur (Mason, 1994:213).

Team members, who succeed in dealing with changes, have recognised and accepted the fundamental reality that success requires collaboration with other team members. Secondly team members 
are committed to the idea that everyone is responsible for managing and solving problems that stem from changes (Rothermich et al. 1996:18).

The last element team members commented on, as an ingredient for the creation of an effective team, was fun and the use of humour.

\section{Humour/fun}

A sense of humour is desirable for each team member. Team members will put more into their work, if they enjoy their jobs and if they are passionate about what they do.

Team members said, "We want more fun ... fun in a team creates success". "We would like having a breakfast together and just sit down and talk". "Lets create a social club where we can get together and have fun". "Fun activities in team-building sessions will enhance personal relationships".

According to Umiker (1989:60) frequent small celebrations and occasional large ones, not only lift team members' spirits, but also show that the organisation cares. These activities can consist of anything from serving doughnuts to elaborate dinners. Once in a while the Chief Executive Officer (CEO) can also be invited to celebrate with team members. Celebrations can be orchestrated through award giving ceremonies. These awards need not be fancy, but can be simple but meaningful. These celebrity awards can become part of an annual retreat for team members. This enhances reflexivity amongst team members so that they ultimately can learn how to praise each other (Russell-Babin, 1996:232).

Following is a short outline of proposed guidelines for building a winning team. This would be a team that will ultimately be responsible and accountable, have a clear direction, can manage change in a constructive way and is happy and productive - as an emotionally intelligent team with emotionally intelligent individual team members. When individu- als and teams are able to display these characteristics, their mental health will also be promoted in this process.

\section{Guidelines for building a mentally healthy team}

Guidelines were deducted from the results and a literature control. The proposed guidelines are provided in the form of a short process outline.

\section{Process outline}

Creating a climate conducive for building trust within a team. Trust is of vital importance in the establishment of any relationship. The authors name the initiation and maintaining of this relationship, the joining phase and this phase will be followed by a journey of self-discovery.

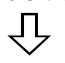

Structure within the team and organisation is of crucial importance to ensure safety and direction within the team:

- Setting the rules.

- The processes of establishing a clear vision and mission statement, as well as company goals and a core value system.<smiles>[C+]1=C[C+]=CC1</smiles>

Diagnosing team reflexivity in order to allow members to open up towards one another.<smiles>[TeH]</smiles>

Participative management through CEO involvement to align goals - strategic planning.<smiles>[TeH]</smiles>

Enhancing interpersonal and life skills through experiential exercises, case studies, role-play (problem-solving; conflict management; communication skills).

Managing and addressing complexity (chaos) within team and addressing poor performance by referring to the theory of constraints; managing change in teams by enhancing lateral thinking skills.<smiles>[Te]</smiles> 
Continuous performance appraisal. This is done twice a year.

$$
\text { § }
$$

DISC profiles to create self-awareness (intra-personal) and interpersonal awareness within the team. \

\section{EQ (Emotional Intelligence)}

All successful teams/team leaders are alike in one crucial way - they have a high degree of emotional intelligence.

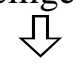

Self-awareness

\section{LIMITATIONS}

In this company, all managers are included in teambuilding, and they do not really have a choice, as this is company policy. Initially the researchers experienced a lot of resistance, and researchers thought that it might be because team members felt "forced" to attend the sessions. This was a stumbling block and it took more time to build a trusting relationship with team members. After a few months, however, they could reflect back on their experiences, and only describe it as very positive. The fact that managers are still required to attend team-building could possibly be rephrased to them in a different and positive way.

\section{CONCLUSION}

It is clear that teamwork is necessary to effectively address the economics and the quality of service employees render today. Understanding the elements for and potential obstacles to successful teams are very important. Redesigned organisations will support teamwork with an emphasis on cooperation and organisational goal achievement.

It is also clear that organisations and teams are very dynamic and change occurs on a frequent basis, therefore team-building is never a once-off session, but a process that should be continuous.

This is also very true of health care organisations, as many of these obstacles are also identified in many health care settings in South Africa today.
凹<smiles>[Te]</smiles>

Motivation

Self-regulation

Many items of the literature studied and perused for the literature control, referred to health care settings all over the world. The way to go forward in ensuring quality service to all users of health care delivery systems is ensuring the team based approach in the health care delivery system (AntaiOtong, 1997; Ashton \& Wilkerson, 1996; Crossley, 1994; Dalton, 1996; Eggart, 1994; Freiburger, 1996; Kneedler, 1988; Lynch, 1981; Mason, 1994; Mantley, 1994; \& Norville, 1983).

"Remember, it is said that people are your greatest assets. We need the synergistic energy and creativity of teams to identify new ways of doing things that result in less cost while continuing to provide the quality of service desired" (Kneedler, 1988:21).

\section{REFERENCES}

Antai-Otong, D 1997: Team-building in a health care setting. AJN, 97(7):48-51.

Ashton, JT \& Wilkerson, J 1996: Establishing a teambased coaching process. Nursing Management, 27(3), March 1996.

Black, ME; Everett, I; Green, E; Krilyk, J \& Van Berkel, C 1994: Transforming people: Creating a superteam. C JONA, May/June 1994.

Bonsetter, BJ; Suiter, JI \& Widrick, RJ 1993: The universal language of DISC - A reference manual. Target Training International.

Burns, N \& Grove, SK 1993:. The practice in nursing 
research; $2^{\text {nd }}$ edition. Philadelphia, PA Saunders.

Burns, N \& Grove, SK 1987: The practice in nursing research. Philadelphia, PA Saunders.

Brodsky, S; Runcie, D \& Lichtenstein, B 1996: Constructive feedback in organizational team-building. Occupational Medicine, 11(4), Oct-Dec 1996.

Creswell, JW 1994: Research design: Qualitative and quantitative approaches. Thousand Oaks, California: Sage.

Crossley, BA 1994: Team-building with personality. Nursing Management, 25(8).

Democratic Nursing Association Of South Africa 1998: Ethical standards for nurse researchers. Pretoria: Democratic Nursing Organisation of South Africa.

Dalton, J 1996: Make high performance teams work for you. MLO, February 1996.

De Moville, C; Hogeda, C \& Varnadore, K 1996: Success in today's environment: How to form an effective work centered team. CEU, 1996:12-17.

Elledge, RL \& Phillips, SL 1989: Team-building for the future. Johannesburg: Pheiffer and Company.

Eggart, M 1994: Team playing. Nursing Standard, April 1994, 8(28).

Fitzpatrick, MA 1996: Interdepartmental collaboration: Focus on outcomes. Seminars in Perioperative Nursing, 5(1), Jan 1996.

Freiburger, OA 1996: A collaborative approach to teambuilding between staff and students in long-term care.

Nurse Educator, 21(6), Nov/Dec 1996.

Giorgi, A ed. 1985: Phenomenology and psychological research. Pittsburgh, PA: Duquine University Press.
Goleman, D 1998: Working with Emotional Intelligence. Bloomsbury Press.

Krefting, L 1991: Rigor in qualitative research: The assessment of trustworthiness. The American Journal of Occupational Therapy, 45(3):214-222.

Krueger, PA 1994: Focus groups. London: Sage.

Kneedler, JA 1988: Creating the "A” team. Today's OR Nurse, 10(10), Oct 1988.

Lengacher, CA; Mabe, PR; Van Cott, ML; Heinemann, D \& Kent, K 1995: Team-building process in launching a practice model. Nursing Connections, 8(2):51-59.

Lincoln, YS \& Guba, EG 1985: Naturalistic enquiry. Beverley Hills: Sage.

Lynch, B 1981: Team-building: Will it work in health care? Journal of Allied Health, Nov 1981.

Mason, JK 1994: Building the team during consolidation. Seminars for Nurse Managers, 2(4), Dec 1994.

Mouton, J \& Marais, HC 1990: Basiese begrippe: Metodologie van geesteswetenskappe. Pretoria: Raad vir Geesteswetenskaplike Navorsing.

Manthey, M 1994: Team-building on the fast track. Creative Nursing, Sept, 5-9.

Morse, JM \& Field, PA 1996: Nursing research. The application of qualitative approaches. London: Chapman and Hall.

Norville, JL 1983: Team-building techniques for the health care supervisor. Beverly Hills: SAGE.

Phillips, SL \& Elledge, RL 1994: The team-building source book. San Diego: University Associates Inc.

Prehn, RA 1996: Building an effective team. REHAB management, Dec/Jan 1996. 
Rothermich, AE ; Kinnear, CL \& Beck, SL 1996: From unpleasant surprises to productive relationships: becoming team builders. Hospital Topics, 74(4).

Rennecker, JA 1996: Team-building for continuous quality improvement. Seminars in Perioperative Nursing, 5(1):40-46.

Rush, D \& Sheldon, M 1996: On becoming a team: a view from the field. Seminars in speech and language, 17(2), May 1996.

Russel-Babin, K 1996: Team-building for the staff development department. Journal of Nursing Staff Development, Sept/Oct 1992.

Umiker, NR 1989: How team-building helps reduce turnover. Medical Laboratory Observer, Nov 1989.

Wilson, HS 1989: Research in nursing; $2^{\text {nd }}$ Edition. California: Addison Wesley. 